Uniwersytet Przyrodniczo-

Humanistyczny w Siedlcach

Siedlce University of Natural

Sciences and Humanities

https://bazawiedzy.uph.edu.pl

\begin{tabular}{|l|l|}
\hline Publikacja / Publication & $\begin{array}{l}\text { Из истории украинской комениологии: Андроник Степович (1856-1935), } \\
\text { Mnich Ludmiła }\end{array}$ \\
\hline $\begin{array}{l}\text { DOI wersji wydawcy / Published } \\
\text { version DOI }\end{array}$ & http://dx.doi.org/10.5604/01.3001.0013.6261 \\
\hline $\begin{array}{l}\text { Adres publikacji w Repozytorium } \\
\text { URL / Publication address in } \\
\text { Repository }\end{array}$ & https://bazawiedzy.uph.edu.pl/info/article/UPHee739794c8b3424eb1686d1d8ee36ce0/ \\
\hline $\begin{array}{l}\text { Data opublikowania w Repozytorium } \\
\text { / Deposited in Repository on }\end{array}$ & 22 paź 2021 \\
\hline Rodzaj licencji / Type of licence & Attribution-NoDerivs (CC BY-ND 3.0) О \\
\hline Cytuj tę wersję / Cite this version & $\begin{array}{l}\text { Mnich Ludmiła: Из истории украинской комениологии: Андроник Cтепович } \\
\text { (1856-1935), Siedleckie Zеszуty Котепіоlogicznе seria PEDAGOGIKA, vol. 6, }\end{array}$ \\
\hline
\end{tabular}




\title{
ИЗ ИСТОРИИ УКРАИНСКОЙ КОМЕНИОЛОГИИ: АНДРОНИК СТЕПОВИЧ (1856-1935)
}

\author{
FROM THE HISTORY OF UKRAINIAN COMENIUS STUDIES: \\ ANDRONIK STEPOVICH (1856-1935)
}

DOI: $10.5604 / 01.3001 .0013 .6261$

\begin{abstract}
Резюме: Статья посвящена анализу текста Андроника Степовича (1856-1935) Ян Амос Коменский, славянский педагог и мыслитель в контексте российской и украинской комениологии. Автор статьи приходит к выводу, что доклад Степовича является важным звеном украинской комениологии конца XIX века, в которой нашли свое отражение основные тенденции русской комениологии того времени (славянофильский акцент), а также черты украинской комениологии (отсутствие антикатолического пафоса). В статье также отмечается прогрессивный «целостный» подход Степовича к изучению наследия Коменского.
\end{abstract}

Ключевые слова: Ян Амос Коменский, комениология, Андроник Степович, российская комениология, украинская комениология.

Abstract: This article is devoted to the analysis of Andronik Stepovich's text John Amos Comenius, the Slavonic Pedagogue and Thinker in the context of Russian and Ukrainian Comenius Studies. The author of the article concludes that Stepovich's report is an important stage in Ukrainian Comenius Studies at the end of the 19th century. In this text main trends of Russian Comenius Studies of that time (Slavophil accent) as well as features of Ukrainian Comenius Studies (the lack of anti-Catholic pathos) were reflected. The article also notes Stepovich's progressive "holistic" approach to the study of Comenius's heritage.

Keywords: John Amos Comenius, Comenius Studies, Andronik Stepovich, Ukrainian Comenius Studies, Russian Comenius Studies

В конце XX - начале XXI века изучение наследия видного чешского мыслителя XVII века Яна Амоса Коменского (1592-1670) приобрело уже систематический характер, оно отличается тематической разнонаправленностью и главное - интердисциплинарностью. Комениология 
из направления исследований в области прежде всего историкопедагогического знания, какой по преимуществу она была в XIX веке, а также в начале XX века (а в России и Украине и в советское время), превратилась в «интердисциплинарное изучение наследия великого чешского философа, педагога, политического и религиозного деятеля XVII века Я.А. Коменского» (Мельников, 2015: 3). В странах Европы (Чехия, Германия, Украина, Франция, Нидерланды), в России, Китае, Южной Корее и Японии существуют научные сообщества (центры), изучающие работы Коменского в разных областях знания, пополняя наше представление об идеях великого ученого и их актуальности для современности. Здесь нужно также отметить и польские комениологические издания, прежде всего периодические издания Естественно-гуманитарного университета в Седльце: «Studia Comeniana Sedlcensia», «Siedleckie Zeszyty Komeniologiczne», «Orbis Comenianus».

Возвращаясь к ситуации в России и Украине, следует отметить, что всплеск интереса к личности и творчеству Коменского в среде русских и украинских ученых был связан с двумя юбилеями 300-летием и 400-летием со дня рождения Коменского, то есть соответственно в 1892 и 1992 годах. При этом мы должны помнить о всех проблемах, связанных с разграничением русской и украинской комениологии, о чём сегодня идут острые дискуссии, особенно среди украинских исследователей Коменского. Первая проблема связана с языком публикаций о Коменском в XIX и даже XX веке: очень часто исследователи, которые по происхождению были украинцами, писали свои научные работы на русском языке, так как в XIX веке на территории Украины, входящей в состав Российской империи, это был язык научного общения, вследствие запрета на украинский язык («валуевский циркуляр», Эмский указ). Парадигматически такая ситуация напоминает нам ситуацию словацких учёных, которые писали свои работы по-чешски или даже по-немецки в условиях единого государства. Самый яркий пример - это виднейший словацкий комениолог Ян Квачала (1862-1934), который основные свои тексты опубликовал на немецком или чешском языках.

Вторая проблема, которая касается самоопределения украинской комениологии, это проблема территориальных границ Украины в XIX и в XX веке, когда украинцы жили в разных государствах (прежде всего в Российской и Австро-Венгерской империях), и соответственно тоже писали свои научные работы на разных языках - 
русском, немецком, польском, украинском, словацком. Таким образом, понятие украинская комениология является весьма сложным в плане историческом и содержательном. В данной статье мы рассмотрим работы украинского по происхождению и образованию учёного Андроника Степовича (1856-1935), все комениологические тексты которого были написаны на русском языке. Исходя из выше сказанного, можно говорить о русскоязычной украинской комениологии, к которой и принадлежит рассматриваемый нами учёный.

Обобщая имеющийся на сегодня материал комениологических исследований, можно определить три аспекта, связанные с разграничением украинской и русской рецепции Коменского (более детально об этих различиях я пишу в другой статье, находящейся сейчас в печати, в данном случае воспользуюсь лишь выводами из этой статьи):

1) Религиозный аспект: для российской рецепции характерно подчеркивание антикатолической ориентации Коменского, что совпадает с антикатолической политикой русского православия; украинская рецепция в этом отношении не является столь радикальной, ибо западная часть сегодняшней Украина (Галиция) принадлежала, а частично принадлежит и сегодня к католическому культурному пространству (часть украинцев - это католики-униаты); поэтому противопоставление Коменского католической церкви не является для украинской комениологии принципиальным.

2) Историко-политический аспект: в рецепции российских ученых Коменский воспринимался последовательно как враг Австрийской империи и враг Польши, в то время как украинская рецепция акцентировала прежде всего борьбу Коменского за независимость собственной страны; для украинцев, которые сами всегда мечтали о независимом государстве, это было очень важным аспектом, в то время как для русской рецепции были характерны панславистические контексты, а Коменский изображался представителем всех славян в их борьбе против германизации славян, которые в свою очередь противопоставлялись неславянам (австрийцам) в своих стратегических планах.

3) Оба упомянутые аспекта связаны с третьим идеологическим аспектом, который в российской рецепции практически отсутствует: для России Коменский важен как педагог и как антикатолик, но не как политический мыслитель; для рецеппции украинской, наоборот, политические идеи Коменского необычайно 
важны; политические планы Коменского, связанные с борьбой против католической церкви в Польше совпадали с планами Богдана Хмельницкого, и именно об этом часто писали украинские историки, отмечая даже возможность переписки чешского мыслителя с канцелярией Б. Хмельницкого.

Возвращаясь к теме нашей статьи, отметим уже упоминаемый особый всплеск интереса к Коменскому в России на конец XIX века, а именно на 1892 год, когда широко отмечался трехсотлетний юбилей мыслителя. Роман Мних в свой статье Ян Амос Коменский и Русская Православная Церковь специально обратил внимание на то, что во всех публикациях русский исследователей о Коменском этого юбилейного года особенно акцентировались два факта: 1) во-первых, то, что Коменский - это представитель славянства, славянин, и 2) во-вторых, то, что чешский народ пребывает в австрийской неволе, то есть речь шла о явной славянофильской тенденции в области комениологии (Mnich R., 2012: 117-125).

Таким образом, рецепция наследия Яна Амоса Коменского, а также ее осмысление в историко-культурном контексте занимала важное место не только в процессе понимания и усвоения идей этого великого мыслителя, философа, теолога и политика, но и в общей идеологии Российского государства, частью которого в XIX века была Украина. При казалось бы достаточно хорошей изученности этой проблемы в России и в Украине, мы имеем сегодня очень много открытых вопросов, требующих новых исследований и новых интерпретаций. Так, например, до сегодня нет полной библиографии рецепции Коменского в России: существующая библиография охватывает время до 1992 года, то есть практически до распада Советского Союза и не учитывает рецепции Коменского в России посткоммунистической и современной. В Украине работа над такой библиографией еще не началась, хотя интерес к Коменскому постоянно возрастает, а среди украинской эмиграции этот интерес никогда не прекращался (достаточно вспомнить работы Дмитрия Чижевского и Панаса Феденко). Кроме этого, изданная в 1995 году в Москве библиография, отражающая русскую рецепцию Коменского (Ян Амос Коменский. Указатель) содержит весьма существенные пропуски. Эти пропуски касаются прежде всего теологических аспектов, а также текстов русских эмигрантов XX века (философов, педагогов, теологов, среди которых такие выдающиеся личности, как, например, Сергей 
Гессен). Именно поэтому в упомянутой библиографии отсутствует упоминание о статьях, посвящённых Коменскому, в разных православных словарях и энциклопедиях, а также не учтены русскоязычные тексты о Коменском таких авторов, как Дмитрий Чижевский, Василий Зеньковский, Иван Лапшин. К этим пропускам мы можем добавить и напечатанные на русском языке в русских эмигрантских журналах и газетах тексты чешских авторов, а также целый ряд статей из русских газет советского периода, особенно тех, которые отражали острые дискуссии вокруг наследия Коменского в Советском Союзе 50-60 годов XX века.

Еще сложнее обстоят дела с украинской коменианой (комениологией), которая не собрана до сегодня и не описана. Исследователи украинской рецепции Коменского не имеют даже самой общей библиографии, а отдельные попытки в этом плане Вернера Кортхаазе, Романа Мниха или Бланки Ержабковой не являются решением проблемы. Подчеркнем специально, что украинская рецепция Коменского принципиально отличается от русской по нескольким причинам, связанным с историческими судьбами украинской науки. Как мы уже упоминали, территория современной Украины была разделена между разными государствами до XX века, поэтому украинская комениология развивалась одновременно как на территории Российской империи, так и на территории АвстроВенгерского государства, а еще раньше - на территории Речи Посполитой, что отразилось на языке (языках) трудов украинских комениологов. Кроме всего этого в плане религиозном Украина была и остается разделенной между католиками, православными, а также и другими религиозными конфессиями. В такой ситуации рецепция наследия Коменского как представителя религиозной общины Чешских братьев, как эмигранта выглядит очень непростой, если учесть, что о нём приходилось писать украинцам, которые сами были эмигрантами и принадлежали к разным христианским церквям.

Вспомним еще раз тот факт, что в России Коменский в XIX и XX веке воспринимался, прежде всего, как педагог и частично теолог, воевавший с католической церковью. Практически все словарные статьи и теологические публикации о Коменском в России, как мы уже отмечали, подчеркивали борьбу чешского писателя против католической церкви, а те русскоязычные исследователи, которые обращали внимание на другие аспекты в жизни и творчестве чешского 
мыслителя, происходили из украинской среды и принадлежали к украинской (малороссийской, по определениям того времени) интеллектуальной элите Российской империи.

В контексте русской и украинской рецепции идей Коменского важное место принадлежит упомянутому выше Андронику Степовичу (Андроник Дудко-Степович). Интерес к работам этого киевского ученого-слависта, историка и педагога возобновился в конце XX века, после длительного перерыва, вызванного идеологическими причинами в советское время. Исследователи наследия Степовича отмечают, прежде всего, его вклад в развитие славистики XIX - начала XX века (Лаптева, 2012: 671-680; Паламарчук, Чмир, 2008: 244-248). Научная деятельность Степовича проходила в среде киевской интеллигенции, а на формирование взглядов будущего ученого сильное влияние имел украинский аристократ-меценат Григорий Галаган (1819-1888) государственный и общественный деятель, основатель знаменитого учебного заведения Коллегии Павла Галагана, соучредитель известной Киевской библиотеки, сегодня - Национальная парламентская библиотека Украины (смотри об этом подробнее: Литвин, 2016).

Несмотря на то, что имя Степовича постепенно выходит из забвения, появляются научные статьи и разделы в монографиях, посвященные этому, достаточно известному в свое время, слависту, тем не менее его интереснейшая публикация, посвященная Коменскому не была предметом отдельного исследования. Речь идет о докладе Андроника Степовича Ян Амос Коменский, славянский педагог и мыслитель, который является частью книги Ян Амос Коменский (1592-1670), изданной в Киеве в 1892 году в Типографии Императорского Университета Святого Владимира. В этом издании наряду со статьей Степовича есть также статья Ф. Яреша Ян Амос Коменский, последний enuскоп Чешских Братьев. Обе статьи, как следует из подзаголовка, представляли собой доклады («чтения») на Торжественном собрании Киевского Славянского Благотворительного Общества, состоявшегося 15 марта 1892 г. в память трехсотлетия рождения Я.А. Коменского. В данном случае мы не будем останавливаться на вопросе о роли и задачах Киевского Славянского Благотворительного общества, поскольку это выходит за пределы тематики нашей публикации, отметим лишь славянофильский характер деятельности этого общественного объединения.

Постараемся на примере статьи Степовича проследить, насколько научный дискурс киевского ученого совпадает с ведущими 
тенденциями комениологических работ конца XIX века в России, а также и в Украине. Стоит отметить, что уже заглавие доклада Андроника Степовича (Ян Амос Коменский, славянский педагог u мыслитель) задает тон восприятия Коменского в контексте принадлежности ученого к славянскому миру, что несколько раз подчеркивает автор в тексте своего доклада, и это представляется вполне закономерным, учитывая упомянутое выше направление общественной деятельности Киевского Славянского Благотворительного общества, членом и даже вице-председателем которого был Андроник Степович.

Приведем теперь несколько показательных примеров-цитат из названной выше статьи с нашими комментариями. Первый важный аспект анализируемого текста касается идеи славянской общности, о которой Степович пишет так: «Мы чувствуем особенное удовольствие от сознания, что чествуемый нами сегодня один из величайших педагогов принадлежит по рождению и убеждениям к нашей великой, но, к сожалению, исторически несчастной славянской семье...» (Степович, 1892: 30, орфография современная - Л.М.). С проблемой несчастья исторических судеб славян связан вопрос о воспитании и просвещении человека, которые (воспитание и просвещение) должны привести к настоящему счастью: «Таким образом славянский гений Коменского заложил в этой книге (Мир в картинках - Л.М.) глубокие основы истинно гуманного просвещения и воспитания человечества.» (Степович, 1892: 44). Степович уверен, что труд и деятельность, чаяния и идеи Коменского были не напрасными, они были подхвачены последующими поколениями ученых: «...сравнив педагогические идеи и деятельность великого славянина с идеями и взглядами следовавших за ним крупных педагогических деятелей, мы должны прийти к убеждению, что надежды Коменского оказались небезосновательными ...» (Степович, 1892: 56).

Следует специально отметить, что очень похожие акценты на принадлежность Коменского к славянству встречаются также в работах и русских ученых. Назовем, например, статью Константина Грота Славянские основы идей и деятельности И.А. Коменского, изданную в том же 1892 юбилейном году (Грот, 1892: 105-119), или работу Николая Бахтина Великий славянский педагог Ян Амос Коменский (Петроград 1915). Особенностью публикации Степовича является то, что он основное внимание уделяет педагогическому наследию Коменского, что следует из 
задачи, которую автор ставит перед собой: «как можно ярче и нагляднее обрисовать писательскую деятельность его вообще, особенно же раскрыть значение его педагогических трудов» (Степович, 1892: 28).

Среди юбилейных комениологических публикаций конца XIX века текст Степовича выгодно отличается следующими аспектами:

1) стремлением к целостному подходу в изучении наследия Коменского;

2) общим обзором научных изданий, посвященных Коменскому;

3) детальным анализом основных трудов Коменского (Дидактика, Мир в картинках, Лабиринт света).

Несмотря на то, что доклад Степовича посвящен в основном педагогическим идеям Коменского, ученый подчеркивает важность целостного подхода к изучению наследия великого мыслителя в историческом контексте его эпохи. Такой подход, по мнению Степовича, должен учитывать и пансофические труды Коменского, и результаты его практической педагогической деятельности, и теоретические педагогические труды Коменского (Дидактика, Открытая дверь языков, Мир в картинках и другие), но также и его языковедческие работы, поскольку Коменский был блестящим языковедом и великолепным знатоком родного языка.

В тексте Степовича дан краткий обзор научной литературы, посвященной изучению наследия Коменского. Обращает на себя внимание великолепная осведомленность автора статьи в области современной ему чешской комениологии (работы А. Патеры, И. Шмаги, И. Клики и других известных в то время исследователей творчества Я.А. Коменского). Это неудивительно, и даже закономерно, поскольку Степович систематически обращался к изучению чешской литературы и шире - чешской культуры, неоднократно посещал Чехию и издал несколько книг по истории чешской литературы. Достаточно назвать такие известные его книги, как, например, Этюды из области новой чешской литературы (Киев, 1881) и Очерк истории чешской литературы (Киев, 1886).

В контексте нашей проблемы стоит также отметить детальный анализ основных произведений Коменского в докладе Степовича. Ученый не ограничивается общими утверждениями о роли Коменского в педагогике, но детально анализирует структуру и содержание его педагогических трудов (Дидактика, Мир в картинках). Но особенно важно, что Степович указывает на оригинальные идеи Коменского, 
получившие свое развитие в западноевропейской педагогике: «...Коменский был в сущности неисчерпаемым источником всех их (педагогов - Л.М.), что они лишь развивали и применяли к современной им действительности его великие, плодотворные идеи, которыми воспользовалось все человечество» (Степович, 1892: 55). Далее автор переходит к конкретным примерам, напоминая, что Коменский разработал основоположный принцип педагогики французского просветителя Руссо - «так называемый «антропологический принцип», состоящий в том, что воспитывать и развивать всесторонне должно прежде всего «человека», а затем уже того или другого специалиста...» (Степович, 1892: 55). Как справедливо отмечает киевский ученый, Orbis pictus Коменского, где впервые был использован принцип наглядности обучения, «послужил образцом для Elementarwerk Базедова и источником педагогических воззрений Песталоцци» (Степович, 1892: 55). Дальше Степович отмечает влияние чешского мыслителя и на других известных европейских педагогов, подчеркивая, что даже такие известные немецкие педагоги Фридрих Фребель (1782-1852) и Адольф Дистервег (1790-1866) свои идеи также черпали из трудов Коменского.

Стоит обратить внимание также на тот факт, что в докладе Степовича отсутствует ярко выраженный антикатолический пафос, присущий русскому научному дискурсу XIX века, и это особенно ощутимо при сравнении двух докладов (Степовича и Яреша), изданных в одной книге. В этой связи припомним также для сопоставления и упоминаемую выше статью профессора Варшавского университета Константина Яковлевича Грота Славянские основы идей и деятельности И.А.Коменского, написанную в антикатолическом ключе.

Важным с нашей точки зрения представляется тот факт, что в отличие от других авторов, Степович не только обращает внимание на то, что Коменский после изгнания из родной земли нашел убежище в Лешне, «что представлялось для него довольно безопасным в виду тогдашней веротерпимости в Польше, еще не подавленной темным господством иезуитов...» (Степович, 1892: 36), но также отмечает продуктивность этого периода как в теоретической, так и в практической педагогической деятельности Коменского: «Здесь же написаны были Коменским и два величайшие его педагогические творения: Великая Дидактика, Отверзтая дверь языков» (Степович, 1892: 36).

Обратим внимание на то, что жанр доклада («чтение») определил стилистические и структурно-композиционные особенности 
текста Степовича. Текст Степовича имеет кольцевую композицию: в начале ученый-славяновед обращает внимание на то, что Коменский опередил свое время, а, в последнем абзаце выражает надежду, что именно в конце XIX века педагогические идеи Коменского будут реализованы: «Мне остается только пожелать, чтобы школа наша, как школа славянская, поскорее воспользовалась великими идеями гениального славянского педагога и применила их к делу в возможной для нашего времени широте и полноте» (Степович, 1892: 60). Для стиля анализированного текста Степовича характерны также черты доклада: 1) научность (библиография, аргументация, цитаты); 2) риторические фигуры, рассчитанные на слуховое восприятие, (повторы, восклицательные предложения, обращения к слушателям); 3) метафоры. То есть, мы имеем дело со всеми важными риторическими приёмами, рассчитанными на устное восприятие высказывания, что, конечно же не преуменьшает научности доклада Степовича.

Анализируемый текст Андроника Степовича отражает самые важные идеи, связанные со взглядами автора на личность и творчество видного чешского мыслителя. Но это не единственная публикация, посвященная Коменскому, которая вышла из-под пера Степовича: он является автором Очерка истории чешской литературы (Киев 1886), где много места занимает характеристика литературной деятельности Коменского. Кроме этого, Степович специально занимался романом Коменского Лабиринт света и рай сердца, и написал специальную статью о русских переводах этого знаменитого произведения (Степович, 1908: 743-750).

Подводя итоги, мы можем отметить, что статья Андроника Степовича является важным звеном украинской комениологии конца XIX века. В этом тексте осмыслены, прежде всего, педагогические идеи Коменского и их значение для развития как западноевропейской, так и славянской теоретической и практической педагогики. В анализируемом тексте свое отражение нашли основные тенденции русской комениологии того времени (славянофильский акцент), а также черты украинской комениологии, то есть отсутствие однозначно антикатолического пафоса, заслоняющего собой истинное значение деятельности Коменского. Стоит также указать на прогрессивный «целостный» подход автора к изучению наследия Коменского. Так, например, Степович, анализируя учебно-воспитательную систему чешского педагога, в первую очередь обращает внимание на ее нравственно-религиозный характер: такой подход к дидактической 
системе Коменского в силу понятных причин будет невозможен в последующие десятилетия после октябрьского переворота.

\section{Библиография}

Mnich Roman, Jan Amos Komeński i Rosyjski Kościół Prawosławny, W: Jan Amos Komeński a Europa XVII wieku / Jan Amos Komenský und Europa im XVII. Jahrhundert, Praca zbiorowa pod redakcją naukową Barbary Sitarskiej i Romana Mnicha. "Studia Comeniana Sedlcensia", tom IV, Siedlce 2012, s. 117-125.

Бахтин Николай, Великий славянский педагог Ян Амос Коменский, Петроград 1915.

Грот Константин, Славянскія основы идей $и$ дпятельности И.А.Коменскаго, «Славянский обзор» 1892, с. 105-119.

Лаптева Людмила, История славяноведения в России в конце XX - первой трети ХХ в., Москва 2012.

Литвин Андрій, Формування світогляду Андроніка Степовича протягом навчання в освітніх закладах другої половини XIX ст. «Історикопедагогічний альманах», 2016, nr 1, с. 58-65.

Мельников Георгий, Изучение наследия Яна Амоса Коменского, „Славяноведение“, 2015, nr 4, с. 3-13.

Паламарчук Ольга, Чмир Олена, Степович - знаний украӥнський ученийславіст і педагог, «Проблеми слов'янознавства» 2008, $\mathrm{nr} 57$, с. 244-248.

Степович Андроник, Ян Амосъ Коменскій, славянскій педагогъ и мыслитель, в: Ян Амосъ Коменскій. Чтенія Ф.Л. Яреша и A.І. Степовича в торжественномъ собраніи.

Кіевскаго Славянскаго Благотворительнаго Общества, состоявшегося 15 марта 1892 г. Въ память трехсотльтія рожденія Я.А. Коменскаго. Киев 1892.

Степович Андроник, «Лабиринт света» в русской литературе, в: Сборник статей, посвященных почитателями академику и заслуженному профессору В.И. Ламанскому по случаю пятидесятилетия его ученой деятельности. Том второй. СанктПетербург 1908, с. 743-750.

Ян Амос Коменский: Указатель русских переводов и критической литературы на русском языке, 1772-1992. Сост. Н.Л. Глазкова. Москва 1995. 